\title{
A SZOVJETUNIÓ POLITIKAI RENDSZERE - 3. RÉSZ
}

Szerző:

Kemény László (PhD, CSc)

nyugalmazott egyetemi tanár

Szerző e-mail címe:

kemeny.m.laszlo@gmail.com

\section{Lektorok:}

Farkas József György

Magyar Újságírók Országos Szövetsége

Gilyán György

ny. volt moszkvai nagykövet

...és további két anonim lektor

\begin{abstract}
Absztrakt
Jelen tanulmány a Szovjetunió (SZU) politikai rendszerének történetérôl szóló sorozat harmadik része, amely az 1985-1991 közötti eseményeket tartalmazza. Az első és a második rész megtalálható a Lélektan és Hadviselés folyóirat 2020/1. és 2020/2. számában.
\end{abstract}

Kulcsszavak: Szovjetunió, politikai rendszer, történelem

Diszciplinák: történelem, politológia

\section{Abstract}

THE POLITICAL SYSTEM OF THE SOVIET UNION - 3r PART

The present study is the third part of a series about the history of the political system of the Soviet Union (SU), which contains the events between the years 1985-1991. The first and second parts can be found in issues 2020/ 1 and 2020/2 of the journal Lélektan és Hadviselés / Psychology and Warfare/. Keywords: Soviet Union, political system, history

Discipline: history, politology

Kemény László (2021): A Szovjetunió politikai rendszere - 3. rész. Lélektan és hadviselés interdiszciplináris folyóirat, III. évf. 2021/1. szám. 9-21. doi: 10.35404/LH.2021.1.9 


\section{Gorbacsov kísérlete}

\section{a Szovjetunió}

\section{politikai rendszerének reformjára}

Döntő fordulatot jelentett a Szovjetunió sorsában Mihail Gorbacsov színrelépése. A világban és odahaza is mindenki várta, hogy Ô lehet - és legyen is - a „korszakváltás” embere. A „levegőben” az vert már egy évtizede hullámot, hogy el kell dőlnie melyik globális hatalom viszi át az emberiséget a tudományostechnikai haladás új korába. Megbékélésre számítottak a népek, s arra, hogy az addig szembenálló ideológiai, gazdasági, politikai erők élén mindkét oldalon innovatív, nyitott szemléletû, karizmatikus és globális döntésekre képes vezető vigye az ügyeket. Az USAban 1981 januárjában megjelent ilyen vezető, Ronald Reagan személyében, s hozta magával a „reaganomics” megújulási politikát. A Szovjetunióban - az elemzett folyamatok stációit maga mögött hagyva - végül ilyen szerepre választódott ki 1985-ben Mihail Gorbacsov.

A világ várakozása annyiban pozitív eredménnyel teljesült, amennyiben a hidegháború abbahagyásával sikerült elkerülni a nukleáris összecsapást. Ugyanakkor a Szovjetunió számára ez a kiegyezés, olyan „kompromisszumot" tartalmazott, amelyben egységes államként felmorzsolódott, s az örököseként reinkarnálódott Oroszország pedig rákényszerült a társadalmi rendszerének a szinkronizálására, a kapitalista berendezkedésű fejlett országokéval.

Gorbacsov szerepe itt véget ért. A fordulat már nem az általa elképzelt forgatókönyv szerint történt. A tanulságok miatt mégis fontos megismerni a törekvéseit, a történtek menetét és következményeit, amelyekből kinőtt egy új ország, a megváltozott körülményekhez alakított sajátos rendszerével. Amikor áttekintjük a folyamatot, akkor három szakaszt különíthetünk el:

- a még létező Szovjetuniónak a hidegháború befejezése érdekében folytatott küzdelme során, a politikai rendszerében szükségesnek vélt átalakítások elindítása;

- a Szovjetunió megszűnésével, a helyére lépő és újjászülető Oroszországi Föderáció társadalmi-politikai rendszerének „típusáért" vívott harc;

- Oroszország új politikai rendszerének konszolidációja és annak fejlődési állomásai.

Az SZKP főtitkári tisztségébe kerülve, Gorbacsov öröksége a szovjet-szocialista politikai rendszer „brezsnyevi-mutánsa” volt. Ennek alapja a „pangás jellegû szocializmus”, amelyben mindenki megkapta - a gazdaság állapotához kapcsolódóan, kismértékben „plusz-mínuszban billegő” - államilag garantált juttatásait, s ezen felül pedig magáról gondoskodhatott a kapcsolatrendszere hasznosításával. Az állam ,pártfelügyelet” alatt - az 1977-s Alkotmány 6. cikkelye biztosította jogalap szerint - „gúzsba kötve táncolt". Gorbacsov számára ezért a legsúlyosabb tehertétel volt, annak a szervezetnek a szerepét megtalálni a reformjaiban, amelynek az élén töltötte be az ország első emberének posztját.

Természetesen nem lehet mellőzni a politikai rendszer állapotának és reformálhatóságának a kritériumait vizsgálva a globális és más területekhez kapcsolódó hazai körülményeket sem - jelentős mértékben ezt megtettük az előző fejezetekben - mégis itt a „,rendszerszervező” elemre, vagyis a „párt- 
állam - állampártjára" koncentrálunk. Ezt tette a Főtitkár is, amikor rájött, hogy a Szovjetunió további létének és társadalmi-formációjának a kulcskérdése az SZKP sorsa, és helyének, szerepének a megtalálása a peresztrojka menetében. Olyan problémára kellett választ találni, mint ami végig kísérte a szovjetszocialista rendszer egész történelmét: miként valósíthatóak meg a szocialista célkitűzések vegyes-tulajdonviszonyokra épülő piacgazdaság esetén?! Azt már a NEP és a hruscsovi, majd a koszigini gazdasági reformok kudarcai mutatták, hogy szinte lehetetlen feloldani ezt az ellentmondást, hiszen ha az SZKP magára vállalja a kapitalista jellegű gazdaságot, akkor meggyengíti a saját szociális bázisát, és elégedetlenségeket vált ki a társadalom vagyoni különbségeinek jelentős növekedése.

A viták kiéleződtek a pártban és azon kívül is. A piaci-reformok hazai szorgalmazói, és a szovjet piacra, befektetésekre számító külföld is számos választ várt. Elôször is: mi lesz az „agyaglábakon álló” Szovjetunióval?

Megjegyzés: Az „agyaglábakon álló Szovjetunió” tézist már a '17-s forradalomtól ismételgették, de igazából nem jellemezte az ország állapotát.

Ha szétesik a Szovjetunió, mi lesz az SZKPval, szintén szétesik? Ha mégis megmarad, a hatalma is megőrződik? Megkerülhetetlen sarkalatos problémák kerültek terítékre.

Ennek a kérdésnek a döntő vitája az SZKP 1990-s kongresszusára várt. Előtte számos vita zajlott, s ilyen vitairat volt a szerző- társammal, T. Vinogradszkajával közösen megfogalmazott cikkünk a Novoje Vrémja, 1990. №26 számában: «Без монополии на в асть». Az akkoriak értékelését mai szemmel, lásd: Net1

Az SZKP-ban zajló viták és az 1990-es kongresszusra felkészítő elemzések alapján arra a következtetésre juthattunk, hogy az SZKP továbbra is meg kíván maradni, de a hatalom monopóliuma nélkül szándékozik részt vállalni az átalakulások irányításában. A gorbacsovi koncepcióban a születő politikai rendszer hatalmi struktúrájának párt-szerkezetére vonatkozóan öt variáció átgondolását figyelhettük meg:

1. Megőrződik az egypárt-rendszer, de a hatalmi funkciók átrendeződnek a Párt és a Tanácsok között. Ennek a változatnak a valószínűségét a már sűrűsödő elégedetlenségek közepette lehetetlennek tartották, illetve csak abban az esetben vélték megvalósíthatónak, ha ,fegyveres-diktatúra" áll mögötte;

2. Lehetővé teszik a többpárt-rendszert, de azzal a feltétellel, ha az SZKP megörzi a vezető szerepét, és koalíciót alkot a szocialista elveket valló, s vele együttműködni kész pártokkal. Miután az alkotmány nem engedélyezte a szocializmust ellenző pártokat, ebben a változatban ellenzéki pártok nem lehetségesek. Egyrészt, az ekkorra már csak volt szocialista országok tapasztalatai azt mutatták, hogy ilyen ,pszeudó-többpártrendszer” életképtelen; másrészt a Szovjetunióban gyakorlatilag már kialakultak az ellenzéki politikai erők, s 
ebből jött a következtetés: ezt a variációt csak erővel lehetne fenntartani;

3. A még elérhető optimális változatnak az tûnt, hogy törvényesen szabad utat adnak a többpártrendszernek, amelyben lehetséges a szocializmust ellenző politikai erők megszerveződése is, de az SZKP egyedül, vagy a vele egyetértő szövetségeseivel koalícióban megmarad vezető erőnek. Ennek a változatnak a megvalósítása ebben a periódusban még lehetségesnek ítéltetett, figyelembe véve, hogy a társadalom többsége támogatta a szocialista irányultságú hatalom fennmaradását. Ugyanakkor ez a megoldás olyan politikai „mester-munkát” feltételezett, amellyel a „gorbacsovi-peresztrojkások” nem rendelkeztek;

4. Még azt a változatot is elfogadhatónak tartották a pártvezetők, hogy a szabad többpártrendszerben a hatalmat nem az SZKP birtokolja, hanem a többi, szocialista elvek megvalósításában érdekelt párt. Ehhez azonban hiányoztak azok a pártok, amelyekben megbízna a kommunista-nomenklatúra, s a létrehozásuk erőfeszítései sem biztos, hogy megfelelő eredményre vezettek volna;

5. Végül, a törvényben biztosított szabad szervezkedés eredményeként - a kialakult társadalmi-politikai szituációban - hatalomra juthatnak a szocializmust elvető politikai erők. Kérdéses, hogy ilyen átrendeződés - a történelmi folyamatok tapasztalatait is figyelembe véve - meg tude valósulni békésen, atrocitások nélkül? Ennek a változatnak a létjogosultságát ugyanúgy elvetették, mint az egypártrendszer erővel történő megőrzését.
$\mathrm{Az}$ részletes bizonyítás nélkül is megállapítható, hogy mindez a „szövevény” a Pártból indult ki és oda is tért vissza. A rendszerszervező elem, a változások mozgás-tengelye, a viszonyítások mércéje a Szovjetunió létezésének egész történelmi vonulatában és a „végjátékban” is, az SZKP volt. Az ország válsága a pártból indult ki és a megoldást is a párt további sorsában, szerepéről gondolkodva kellett keresni. Az első kérdés csak az lehetett, hogy mi váltotta ki az SZKP válságát? Sokan, sokfelől indulva kutatták az okokat. A közvetlen válasz kézenfekvőnek látszott: ha a politika hosszabb távon nem tud olyan eredményeket felmutatni, amelyek a társadalom döntő többsége igényeinek, törekvéseinek megfelelnének, akkor a vele szembeni elégedetlenség növekedése bizonyos kritikus mennyiségnél általános bizalomvesztésbe, a politika kidolgozói és a megvalósítás irányítói vezetőképességének a megkérdőjelezésébe vált át.

„A párthatalom már régen nem népszerű - fogalmazta meg akkor a Novoje Vrémja egyik olvasója - az utóbbi időben pedig már nem is hatékony" (Новое Время. 23.02.1990. ст.6.).

Ugyanakkor az SZKP történelmi szerepét és az „állampárti” mivoltából adódó felelősségét értékelve, sokan aggódtak a jövőjéért a világban. Natalia Ginzburg például bírálta az olaszokat azért, hogy szűklátóan ítélnek. „Amitől most búcsúzunk, az nem a kommunizmus volt, hanem egy szörny kinövése. Egy betegség burjánzása, aminek semmi köze a kom- 
munizmus eszméjéhez - fogalmazta meg miért éppen akkor búcsúztatjuk a kommunizmust, amikor megjelent Gorbacsov (...) Nekünk, akik kommunistáknak neveztük magunkat Sztálin és Brezsnyev idején éppen most kellene megválnunk a kommunista névtől? (...) Gorbacsov kezében a kommunizmus mássá vált, mássá válhat." (Natalia Ginzburg, olasz írónő interjúja, Népszabadság, 1990. 02. 28.).

A Pártot tartották az emberek felelősnek a válságért, s ez a bizalmatlanság hozta felszínre a szervezet belső krízisének mélyebben fekvő okait. Azt nem lehetett akkor még megítélni, hogy a sok-sok egymástól merőben eltérō utat bejárt nációban, a közel húsz millió párttag, az addig alattvalóként fegyelmezett közel háromszáz millió állampolgár tudatában és lelkében hogyan rakódtak le a történtek. Mi tükrözi az emberek érzetét és akaratát: a „Lenin-szarkofághoz" zarándoklók továbbra is végeláthatatlan sora a Vörös-téren, vagy a Bakuban tagkönyveiket égetők mindent megtagadó szenvedélye? S, mire készültek a vezetők, vagy a sokmilliós párt-apparátus, és a már-már számbavehetetlen sokaságú ,informális” szerveződés „ifjútörökjei”? „Harc folyik a hatalomért" - szinte szólamszerūen riogattak a választási kortes beszédek, a „tudálékoselemzések”, a hivatalos és a „számizdat” sajtó. Kik között és miért, milyen hatalomért? A „kártyákba” nem lehetett igazán belelátni.

Megjegyzendő, hogy az akkori iratok döntő részben titkosítva lettek, s a nyilvánossá és kutathatóvá tételük csupán 2016-ban került napirendre. Putyin, elnök 2016. áprilisában döntött az archívumok titkos do- kumentumainak nyilvánossá tételéről az 1930-1989-s időszakra vonatkozóan. Lásd: Net2.

Az ellentmondások mélygyökerű és sûrű szövevényében nem mutatkozott egyszerű feladatnak meglelni a sztálini, a hruscsovi, a brezsnyevi korok messianizmussal és fanatizmussal hirdetett prioritásai szerint kiépült hatalmi-politikai és gazdasági rendszer érdekviszonyait, és az új prioritások kiváltotta érdekcsorbulások és ütközések társadalmi következményeit. „Sehogyan sem tudjuk megérteni - írta a Pravdában G. Atamancsuk, jogászprofesszor - miként történhetett, hogy a hitelesen népi forradalom egy kegyetlen bürokratikus-parancsuralmi rezsimet szült, az pedig - bár úgy tűnt erôs hatalomra épül mégis válsághelyzetbe juttatta az országot (...) most pedig az a paradoxon állt elő, hogy a mindannyiunk által ihletett, várt, szükségesnek tartott peresztrojka hatalmas nehézségekkel halad és nagy veszteségek kísérik" (Правда. 24. 02.1990.).

Számtalan példával lehetne alátámasztani, hogy végső soron a bajok eredőjét a Pártban találták meg. S, ez felszínre hozta a válság mélyebb okait is. „Ez egy nagyon sokrétű válság, de elsősorban a vezető réteg elvimorális krízise - állapította meg többek egyetértésével A. Gelman - a változtatást nem a pangás éveiben kialakított egész vezetőréteg kezdte el. Az új vonalat Gorbacsov és néhány társa dolgozta ki". Éppen ezért - folytatta az ismert és véleményformáló dramaturg - „két felkelést tapasztaltunk egyszerre: a konzervatív apparátus lázadását a peresztrojka kezdeményezői, az új kurzus ellen; és a párttagság, a 
dolgozó tömegek felkelését a reakciós apparátusok ellen” (Новое Время. 09. 02. 1990.). Ez a markáns megfogalmazása annak a nézetnek, mely szerint a problémát a helyi kiskirályok basáskodása, az apparátusok bürokratikus hatalomgyakorlása, a vezetők kontraszelekciója és személyes ambícióikból is adódó hatalmi torzsalkodása, s a különböző szintû vezetők elidegenedése a tagságtól, a néptől váltotta ki. Végső soron pedig a probléma okaként, mind szervezetileg, mind munkastílusban a „lenini párt” felfogástól való eltávolodásban találták. Ez a nézet láthatóvá vált az SZKP KB 1990. februári plénumán (lásd: Net3, Net4), ahol a szembenállástól és a politikai törésvonalaktól kezdve, a területi pártvezetők tüntetések általi „dominószerű” leváltásával folytatva, egészen az apparátusok szélnek eresztéséig, a pártszékházaknak a gyermekotthonok, kórházak számára kisajátításáig, minden napirendre került. Ebből a megközelítésből arra a következtetésre jutottak a párt legfelső vezetésében, hogy a válságot a peresztrojkát támogató reformerők és a hatalmi pozícióikat védelmező konzervatívok léte és harca okozza. Elég lesz egységes, „peresztrojka hü” vezetést teremteni, megtisztítani az apparátusokat, felszámolni az elbürokratizálódott, hatalmaskodó vezetői stílust stb., és a Párt ismét visszanyeri cselekvőképességét, a bizalmat maga iránt, és sikeresen át tudja alakítani az országot.

Ekkor még kevesen értették meg, hogy másról van szó: a Pártról alkotott addigi felfogás nem felel meg a fejlődés realitásainak és a globális világba illeszkedés követelményeinek. A vezetői, elvi-morális problémák ennek a tüneti megnyilvánulásai, s jórészt azért alakultak ki, mert a Párt strukturális, identifikációs válság- ban volt. Az állampárt jelleg, a hatalom monopolizálása nem tette lehetővé az individuális alkotó energiák felszabadulását, a különböző értékek és érdekek érvényesülését, a valóságos „néphatalom” demokratikus működését. A párt egyik főideológusa, Butenko professzor a Pravdában megjelent vihart kiváltó írásában keserūen tette fel a kérdést: ,azon, hogy milyen érzés egyszerű kommunistának, gondolkodás nélküli kis 'csavarként', néma statisztaként a Moszkvából érkező vezetőitől várni a »fővárosi bölcseletet« kevesen meditáltak el eddig. Még kevésbé vették számításba a pártonkívülieket. Az életet »átszabva« senki nem tartotta szükségesnek legalább azt megkérdezni a pártonkívüliektől, hogy milyen mély a boldogság, amelyet olyan önzetlenül ajándékoz nekik a párt?” (Правда. 28. 02.1990.).

Hоzzá kell azonban tenni, hogy Butenko
jelentette meg korábban több kötetben
(Бутенко, 1984; Бутенко, 1987; Бутенко,
1988; Бутенко,1989) a „,szocializmus meg-
ingathatatlanságáról és a kapitalizmust már
régen meghaladott jelentőségéről” a vi-
tákat kizáró múveit. Személyes találko-
zásunkon - az Oleg Bogomolov, akadémi-
kus által vezetett Gazdasági Intézetbe hív-
tak meg beszélgetésre a magyarországi áta-
lakulásokról - azt kérdezte tőlem: „Na,
milyen is volt a magyar-szocializmus?”
Mire azt feleltem: ,amilyenre ön lefestette
a könyveiben!” S, ezzel Butenko be is
fejezte a tudakozódást. Később, Butenko
tipikus képviselöje lett a „neofita” meg-
nyilvánulásoknak (vesd össze: Бутенко,
1990; Бутенко, 2001).

Az volt tehát itt az igazi kérdés, hogy a vezetői, apparátusi, működésbeli stb. torzulások 
történelmi „véletlenek”, a napi, folyó munka „selejtjei” voltak, vagy annak a szervezetnek a lényegét fejezték ki, amely addig a szovjet társadalomnak a vezető erejeként funkcionált?! Az erre a kérdésre adott választól nem csak az függött, hogy a párt átalakítása érdekében milyen lépéseket kell tenni, hanem ettől függött az átalakítás sikerének a lehetôsége is. Butenko kertelés nélkül kimondta, hogy a „lenini új típusú párt” a politikai hatalomért vívott harc eszközeként jött létre és az is maradt. A „bolsevik” típusú párt sem Lenin életében, sem az azt követő történelmi folyamatokban nem vált a ,hatalmat gyakorló nép pártjává”, mert maga lett a hatalom gyakorlója. A hatalmat kezdettől fogva elvette a nép által választott tanácsoktól, s a pártállami apparátus, a pártállami funkcionáriusok kezében összpontosította.

A „bolsevik” típusú párt soha sem volt a politikai hatalomért a parlamentben vívott harc eszköze, miközben a „vegyes-tulajdonra” épített társadalmi berendezkedés parlamenti demokratikus viszonyai közepette pontosan erre lett volna szükség. A világ civilizációs hatásai és a hazai érdek-pluralizmus következtében szükségszerūen a gorbacsovi-Szovjetunióban is kiépülőben volt a polgári-demokrácia jogállama, s az intézményesült különböző politikai erők a demokrácia szabályai szerint ennek keretében vívták meg a harcukat a politikai hatalomért. Ebben a harcban döntő szerep várt a humánus, a demokratikus szocializmusért parlamentáris módon fellépő, belsőleg is demokratikusan múködő kommunista pártra. Ennek belátásával, együtt járt az is, hogy tudomásul veszik: nem lehetnek alkotmányban garantáltan, egyedüli, kizárólagos birtokosai a hatalomnak, hanem elhagyva a közvetlen hatalmi, ú.n. „parancsuralmi” rendszert, leválva a politikai hatalomról, azt visszaszármaztatják a tanácsokon keresztül a népnek. Közben válaszra várt az a kérdés is: ha a párttól elkerülnek a hatalmi funkciók, akkor mivel tölti fel a ,veszteségeit”, mi az az új, ami a pártban kialakulhat, s mire építheti ezek után a tekintélyét? Felvetődött: „lehet, hogy nincs is tovább szükség a pártra"? Vagy, ha mégis, akkor milyenre, mi legyen a programja, a jellege, s a megújulást a fent jelzett követelmények szerint el lehet e várni az SZKP-tól?

Az SZKP első emberére, Mihail Gorbacsovra várt ezeknek a kérdéseknek a megválaszolása, méghozzá olyan közegben, ahol a már jelzett alapvető probléma, a peresztrojkában születő politikai rendszer hatalmi struktúrájának párt-szerkezetére vonatkozó variációk közötti választásban kristályosodott ki. Az vitathatatlanná vált, hogy az állampárti jelleg nem tartható fenn, s az is, hogy többpártrendszer alakul ki. Tényként könyvelték el az állam „pártállami” rendszerének lebontását is. Az SZKP felelőssége - elsősorban Gorbacsové - abban csúcsosodott ki, hogy a bontások és az új rendszerekre áttérések folyamatában el ne veszítsék magát a „Pártot”! Ez a dilemma azért foglalkoztatott minden szinten mindenkit, mert rendelkezésre álltak a volt szövetséges kelet-európai szocialista országok tapasztalatai, ahol szinte kivétel nélkül a „fürdővízzel kidobták a gyereket”, és szétestek, „felrobbantak”, vagy egyszerűen megszűntek a kommunista jellegű pártok.

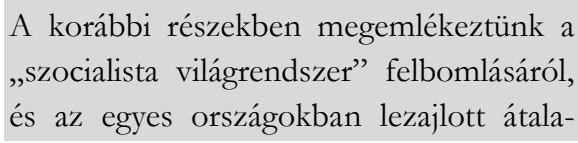




\begin{abstract}
kulásokról. Arról is tettünk említést, hogy Gorbacsov mintegy „kísérleti-terepnek” használta a kelet-európai változásokat. A pártok esetében különösen a lengyel és a magyar történésekre figyelt. Kiemelten érdekelte például, hogy miként kezelte Kádár János a helyzetet, $\mathrm{s}$ folyamatos kapcsolatot tartott vele és az ôt követő pártvezetőkkel. Lásd erről: Földes (2015).

Személyes megjegyzés: az MSZMP 1988-as Pártértekezletén úgy adódott, hogy a szünetben Grósz Károly mellénk szegődött (Mucsi Ferenc történész professzorral értékeltük a helyzetet) és hosszú időn keresztül mesélte, hogy „az előbb Gorbacsovval tárgyalt, aki kérte, vigyázzunk Kádárra”. Később - 2001-ben a TV beszélgetésünkkor - Gorbacsov szintén kiemelte azt a szerepet, amelyet a magyar párt tapasztalata jelentett a számára.
\end{abstract}

Ismerve az egyes országokban lezajlott folyamatokat Gorbacsov számára a tanulságok négy forgatókönyv átgondolását eredményezték az SZKP jövője szempontjából (lásd: Кемень а также Виноградская, 1990):

1) Szétszóródás. Vagyis, az SZKP nem tud megmaradni, de nem részekre szakad, hanem minden szervezettség nélkül szétszóródik, s ez-zel befejezi a létezését. Miután ekkor még az alkotmányban létezett a 6 . cikkely a párt kizárólagos vezető szerepéről, ebben az esetben felborulhatott volna a törvényes rend; hatalmi vákuum alakulhatott volna ki, amelybe nem kontrollálható erők is betolulhatnak, ami a Szovjetunió esetében - a nukleáris biztonság, a szuperhatalmi felelősség stb. - a hazai és a nemzetközi kötelezettségei miatt elfogadhatatlan. Ilyen esetben egyetlen elfogadható lehetséges kiút az elnöki-hatalom bevezetése, politikai és katonai diktatúra formájában. Természetes volt, hogy ennek a forgatókönyvnek a „társadalmi ára” olyan nagymértékben járt volna negatív következményekkel, hogy elfogadhatatlanná vált valamennyi párton belüli és újonnan szerveződő politikai szervezet számára. Így a valószínűsége ekkor még egyenlőnek mutatkozott a nullával

2) Pártszakadás. Akik továbbra is kitartanak a kommunista ideálok és az SZKP mellett, azok megmaradnak „őrzőként” az eredeti pártban. Aki viszont már más ideológiát vall magáénak, vagy az eredetit más szervezetben, másként gondolja megvalósítani, az érdekei érvényesítését szintén új módon igyekszik kifejezni, stb. kiválhat az SZKP-ból és új politikai pártban manifesztálja azokat. Erre akkor van lehetôség, ha a párton belüli különböző nézet- és értékcsoportok, áramlatok képesek kompromisszumot kötni, és békés megegyezéssel szétválnak. A válás után - természetesen - valamennyi új szervezet konkurensévé válik a többinek, beindul a harc a legitimizálódásért, a tömegek támogatásának elnyeréséért, a gazdasági és pénzügyi, a tömegkommunikációs háttér, s a nemzetközi kapcsolatok biztosításáért. Az alkotmányos rend még törvényesen a megmaradt SZKP vezető szerepét garantálja, de az erôviszonyok változása miatt ez csupán formalitássá és beláthatóan rövid idejűvé válik. Nagy volt a kísértés, hogy az 1990. nyári, XXVIII. pártkongresszust megelőzően, esetleg magán a kongresszuson éppen ilyen pártszakadásra kerül sor. Sokan feltételezték, hogy ez a forgatókönyv vezet a politikai rendszer olyan szerkezetéhez, amelyben megőrződik az SZKP vezető szerepe, de koalícióba kényszerül a 
szintén szocializmust, de más módon akaró pártokkal. A helyzetfelmérés és az egyéni ambíciók azonban még nem tették lehetôvé a békés megegyezés kivitelezését.

3) Konszolidálódás. A párton belüli áramlatok kiegyeznek az értékelésekben a párt továbbiakban vállalható ideológiájáról, a lemondásáról a hatalmi monopóliumáról, az új szerepérôl és viszonyáról az állam politikai intézmény rendszerében, stb. Aki ezzel nem ért egyet, az magától lemorzsolódik, s a párt „megtisztulva” a gorbacsovi-peresztrojka vonulatát viszi tovább. Az 1990-re kialakult helyzetben ez a forgatókönyv már nagyon „rezgő léccel” vált kivitelezhetôvé, holott Gorbacsov a legnagyobb erőfeszitést éppen ennek érdekében tette. Különösen Jelcin kiszorítása tartozott ehhez a változathoz. Arra számított, hogy az önálló oroszországi Kommunista Párt megalakulásával „kihúzta a szőnyeget" az orosz állami függetlenséget favorizáló politikai erôk alól, és nem tudnak úgy megszerveződni, hogy szakításra kényszerítsék az SZKP-t. Ez az elképzelés realizálódott is. A XXVIII. Kongresszuson Jelcin egyedül maradt: ugyan látványosan kivonult, de nem mentek vele a beharangozott támogatói. Az „új eszmék” alapján konszolidált SZKP-nak reális esélye képződött az ország kivezetésére a válságból, a peresztrojkához kötődő „egészséges” erők összefogására. Ugyanakkor a realitás azt is magában foglalta, hogy ez csak esély, és a valóságos tisztulás nélkül az is marad.

4) Stagnáció. Abban az esetben, ha a párt az ország megváltozott helyzetéhez, szükségleteihez az átalakulásának konszolidációs esélyeit nem képes realizálni, akkor bármelyik korábban vázolt forgatókönyv valósulhat meg, vagy visszaesik minden a pangás, a változásra képtelenség állapotába. A XXVIII. kongresszust követő ,nagy levegővétel” kifújásával, 1990 év végére ez a stagnáció, a rendszer „lefagyása” be is következett.

\section{Egy meg nem valósult négy lépcsős müveleti sorrend}

A Szovjetuniónak a civilizációs fejlődés fő útvonalára állításának követelménye egyértelművé tette Mihail Gorbacsov számára, hogy a hidegháború abbahagyása, s a külső/belső elzártság feloldása, a nyitottság megteremtése mellett, a legfontosabb az alkotó társadalmigazdasági viszonyok szabaddá, demokratikussá tétele, s ennek garanciájaként a „pártállami” rendszer lebontása és helyette a dinamizmust kiváltó és ösztönző politikai rendszer megteremtése. Azt is látnia kellett, hogy a pártállam szerkezetének a szétszerelése nem járhat együtt a Szovjetunió társadalmi-gazdasági formációjának, a szocializmusnak a megtagadásával, s így annak ,ideológiai-politikai burkát” képező Kommunista Pártjának a felszámolásával. A piacgazdasághoz szükséges vegyes - de a magántulajdont szabaddá tevő tulajdoni viszonyok, s a belőlük fakadó plurális érdekviszonyok, demokratikus többpártrendszerū politikai szisztémájának kialakítása - amelyben a Kommunista Párt demonopolizált vezető szerepe érvényre juthat - Gorbacsov elképzelése szerint négy lépcsős „műveleti sorrendben" valósulhatott volna meg (részletesebben lásd: Виноградская а также Кемень, 1990):

1) „Minden hatalmat a Srovjeteknek"! Megjegyzés: A „minden hatalmat a szovjeteknek” kezdeményezés, a hozzá kapcsolt állam-elnöki funkció bevezetésével nagy vitát váltott ki a 
már formálódó rendszer-ellenzki erőkben. (Lásd errôl: Net5). A szituáció rendszerszerū értékeléséből logikusan következett, hogy, az új hatalmi struktúra kiépítéséhez és hatékony működéséhez a feltételek biztosításának meg kell előznie a párt átalakítását. Ahhoz, hogy közben ne keletkezhessen hatalmi vákuum, „gyorsított eljárással” bevezették az „elnökirendszert" (megjegyzés: az elnöki-rendszer bevezetésének praktikus okairól, és a megvalósítás „fortélyairól - Szaharov és Gorbacsov személyes érintettségéről! - már részletesebben szóltunk az tanulmánysorozat első részében). Ezzel a „főhatalom” ugyan elkerült az SZKP Politikai Bizottságának kollektívájától, de Mihail Gorbacsov, főtitkár személyében „perszonifikálódva”, az elnöki hatalom egyelőre nem változtatta meg a párt egészének hatalmi pozícióit.

Közben, a helyi tanácsi választások befejeztével, minden szinten kialakultak az alternatív (bár hivatalosan még nem többpárti!) jelöltekből a legitim népképviseleti szervek. Az ország legfelső törvényhozó testületeiben - a népi küldöttek kongresszusán, a Legfelsőbb Tanácsban - ott voltak és (ekkor még a lakosság többségében megütközést keltve) fejtették ki nézeteiket a szárnyukat bontogató ellenzéki szerveződések, a valószínűsíthetően jövendő pártok vezéralakjai is. Ez a tény azt is eredményezhette, hogy az ellenzék javaslatai a parlamenten kívüli „kerekasztal-tárgyalásokra" meddőnek bizonyuljanak. A megválasztott képviselők és a tanácsok legitimitása ugyanis jóval magasabb fokú, mint a különböző szerveződések, pártcsírák tárgyalásokat követelő önjelöltjeié.

Mindez arra irányult, hogy először kiépítik az új államgépezetet, s csak azután - illetve részint vele egy időben - bontják le a pártállam struktúráját, alakítják át magát az SZKP-t, hozzáigazítva a már létező feltételekhez. A legitimitásában megkérdőjelezhetetlen és hatékonyan működni képes demokratikus népihatalmi rendszer szerkezeti elemeinek a kiépülésével biztonságosabban gyorsulhat fel a pártállam lebontása, s az SZKP átalakítása is.

2) Az $S Z K P$,peresztrojkája”. Ez a második „lépcső” alulról, a pártszervezetek szintjéről a legfelsőbb irányító szerkezeti elemekig építkezve valósulhat meg. A gorbacsovi elképzelés a párt átalakítása kulcsának a XXVIII. kongresszust tekintette. Az ezt megelőző folyamatban a párttagság megvitatta az SZKP új programjának tervezetét, a szervezeti szabályzatát, vagyis azokat az érték alapokat, amelyekkel az azonosulás vagy elvetésük a tagság részéről eredményezi a folyamat létjogosultságát (lásd: Net6). Ebben a szakaszban dől el igazán a kommunista párt további sorsa: megmarad egységes szervezetként, vagy szétbomlik, leválnak róla a különböző csoportosulások, s esetleg több új párt is létrejön belőle, stb.

A népképviselők III. kongresszusa ekkor már eltávolította az alkotmány 6. cikkelyéből az SZKP monopolhelyzetét garantáló mondatot, de úgy fogalmazta meg a - párttörvény hiányában - még hivatalosan nem létező pártok létjogosultságát, hogy a felsorolásban külön, első helyen a kommunista pártot említette (Net7 - Megjegyzés: a kongresszuson lezajlott vitáról és a döntések jelentőségéről már részletesebben megemlékeztünk a tanulmánysorozat első részében). Az alkotmánymódosítás explicite kimondta a pártok létjogosultságát, és elvileg velük egyenlővé tette az SZKP-t, de egyedüli névszerinti kiemeléssel 
lényegében az alkotmány rögzítette a kommunista párt további létezését és „kiemeltségét”, „különlegességét” a szovjet társadalomban. A párt sorsát illetően az az ellentmondás figyelhető meg, hogy az SZKP-t egy demokratikus jogállam demokratikus pártjaként akarták láttatni, de úgy, hogy megőrizze kitüntetett szerepét, vagyis a „burok-biztosítékot” a politikai berendezkedés szocialista jellege felett. Az SZKP átalakulása az alkotmánymódosítás ilyen szövegével, egyfajta védettséget kapott: nem a hatalomért folytatott - az ország válsághelyzetéből következően valószínúleg kilátástalan - küzdelem, hanem a saját maga által felismert szükségszerűség motiválhatta az állampárt lebontásának és a politikai vezető szerepért politikai eszközökkel fellépni kész párttá válásának a folyamatát.

3) Többpárt-rendszer. Így azonban, egyrészt a „kényelem” járhatta át az állampártisághoz szokott tagságot és főként az apparátust, a struktúrát; másrészt viszont az új pártok megjelenése és markáns politikai színrelépése váratott magára - csak az első két lépcső fokozat teljes kiépülése után realizálódhatott. Ebben az időszakban valójában már léteztek és a közvélemény számára ismertekké is váltak a különböző párt-kezdemények, a törvényes létalapjuk azonban még hiányzott, s ez akadályozta a legitim részvételüket a politikai rendszer átalakulásában. Mindenesetre az a döntéshozói szinten is elfogadottnak tûnt, hogy az átalakítás múveleti sorrendjében a harmadik lépcsőfok a pártok törvényesítése, és a többpárt-rendszer alkotmányos elismerése. Előkészítés stádiumában voltak a politikai szervezetek legitimálására szolgáló törvénytervezetek, s elkezdődtek róluk a viták a felkészülés során az SZKP kongresszusra. Ér- zékelhetően ennek a „lépcsőfoknak" a feltöltésére több időt szántak, s legelőbb a 3-4 év múlva következő népképviseleti választások kampányához illesztették volna a pártok teljes jogkörű részvételét.

4) „Harc a hatalomért”. A feltételezés szerint az SZKP képes lesz a következő választásokig „erős politikai szervezetként és nem állampártként" funkcionálni, egyenjogúként a törvények által legitimált többi párttal. A folyamat negyedik stádiumában következhetett volna be a harc a politikai hatalomért, a törvényes keretek között múködő pártok részvételével lefolytatott demokratikus választások keretében. Ezzel vélte a gorbacsovi felfogás befejezni a „népi-hatalom új politikai rendszerének felépítését és berendezését”.

Gorbacsovék tisztában voltak azzal, hogy az ellenfeleik dühödten mondják majd a vádjukat a „hatalom-átmentéséről”. Az SZKP azonban, a peresztrojka kezdeményezésével nem a lemondását „álcázta” a szocialista társadalmi berendezkedés megvalósításának céljáról, nem a „rendszerváltást” készítette elő, amelyben a hatalmat törvényszerűen a létezésétől lényegét tekintve eltérô társadalmi berendezkedés kierőszakolásában érdekelt politikai erők ragadják meg, s nem is a pártok politikaihatalmi „váltógazdálkodásában” gondolkodott. A parancsuralmi, bürokratikus hatalmi rendszertől, a pártállamtól megszabadulás szükségességét ismerte fel, de nem változtatta meg a társadalom fejlődéséről vallott alapvető felfogását.

\section{Zárógondolatok}

A gorbacsovi peresztrojka politikai rendszerének kialakítására vonatkozó stratégia fő eleme volt a pártra épülő állami struktúra 
lebontása és átalakítása a „minden hatalmat a tanácsoknak" elv alapján. A társadalmi-gazdasági formáció, a rendszer szocialista irányultságú célját azonban lényegileg nem kívánták megváltoztatni.

Megjegyzés: a peresztrojka egyik meghatározó ,jelszava” volt a „Több szocializmust - több demokráciát", amely magában foglalta az átépítés tartalmát és módszerét is. Lásd erről: Net8; Net9.

Ugyanakkor az 1990-91-re kialakult hazai és nemzetközi körülmények ,átírták” ezt a stratégiát. A „történelem” átlépett Gorbacsovon! Ezzel a Szovjetunió és az általa megvalósított társadalmi-gazdasági formáció is idejét múlttá lett.

Arról, hogy miért alakult így, s alakulhatott volna e másként? - tovább folynak a viták, és ez sokáig lesz így. A történelem majd kikristályosítja az értékelését. A tényen azonban nem lehet változtatni, és a történtek rendszerszemléletű bemutatását érdemes tanulmányozni (lásd pééldául: Net10, Net11).

\section{Irodalom}

Бутенко А. П. (1988): Власть народа посредством самого народа. Мысль, Москва.

Бутенко А. П. (1989): Современный

сочиализм. Вопросы теории. Политиздат, Москва.
Бутенко А. П. (1990): Исторический тупик и как из него выйти? // Уpaл. 1990. № 9. Бутенко А. П. (2001): Почему у нас не получился социализм в ХХ столетии? // Социальногуманитарное знание. 2001. № 3.

Бутенко А. П.(1984): Сочиализм как мировая система. Политиздат, Москва.

Бутенко А.П. (1987):Теоретические проблемы совершенствования нового строя. О социально-экономической природе социализма// Вопросв философии, 1987.№2.

Виноградская, Т., Кемень, А. (1990): Аилеммы перестройки. Воронеж. Центр Социологических Исследований. 1990.ст.41-61.

Földes Gy. (2015) (Szerk). Kádár János külpolitikája és nemzetközi tárgyalásai 19561988. I. Kádár és Gorbacsov. (453-462) és Utóvédharc (507-535). Napvilág Kiadó, Budapest.

Кемень, А., Виноградская, Т. (1990). Без монополии на власть. Четыре сценария будущего КПСС. Новое Время № 26 22. июня 1990.

\section{Internetes bivatkozások}

Net1: От СССР к РФ: кардинальные изменения в экономике и политике. Web: http://www.historicus.ru/ot_sssr_k_rf/

Net2: ВАадимир Путин подписац указ о рассекречивании архивов. Web: http://www.pravda.ru/news/politics/04 -04-2016/1297297-putin-0

Net3: Материалы Пценума Центрального Комитета КПСС, 5-7 февраля 1990 г. Web: 
http://militera.lib.ru/docs/da/plenum19 90-02/index.html

Net4: Русский швеА в ЦК КПСС - 2. Web: http:/ /www.specnaz.ru/articles/214/21 /2066.htm

Net5: История СССР. Михаиц Сергеевич Горбачев. Web:

http:/ /www.bibliotekar.ru/ussrsssr/4.htm

Net6: XXVIII съезА КПСС: история последнего съезАа партии. Web: http:/ /ria.ru/spravka/20100702/251528 110.html

Net7: Отмена 6-й статьи Конституции СССР о руководящей роли КПСС. Справка. Web: http:/ /old.rian.ru/spravka/20100314/21 3855855.html
Net8: «Больше социализма - больше Аемократии». Политика «гласности» в годы «перестройки». Web: http://reallystory.com/post/166 Net9: А. А. Симон. "Больше демократии больше социализма": язык журнальной публицистики периода перестройки. Web: http://www.philology.ru/linguistics2/si mon-07.htm

Net10: Георгий Бовт. «СССР казался вечным». Web: http://www.gazeta.ru/comments/2015/ 04/23/slovo_na_bukvu_p.shtml

Net11: Аашичев Вячеслав. СССР не был обречён. Web.

http://www.lgz.ru/article/-17-6413-2404-2013/sssr-ne-byl-obrechyen/ 